\title{
Hemipteran Hopper Species Associated with Acid Lime Plants (Citrus aurantifolia L .) in the Sultanate of Oman: Candidate Vectors of Witches'-Broom Disease of Lime
}

\author{
Syed Ali Razvi*1, Rashid Al-Shidi², Najma Mahmood Al-Zadjali ${ }^{2}$ \\ and Yousuf Mohammad Al-Raeesy ${ }^{2}$ \\ ${ }^{1}$ Pest Control Division, Kwality Agri-Farm Services, Deluxe Colony, Tolichowki, \\ Hyderabad 500 008, A.P., India \\ ${ }^{2}$ Crop Protection Research Center, Rumais Directorate General of Agriculture, \\ P.O. Box 50, Seeb 121, Ministry of Agriculture, Sultanate of Oman \\ مراقبة ورصد أنواع النطاط المتواجدة على أثجار الليمون الحامض في سلطنة عمان:

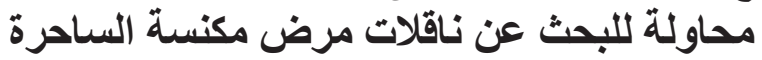 \\ سيد رازفي ور اشد الثيدي ونجمة الزدجالي ويوسف الرئيسي
}

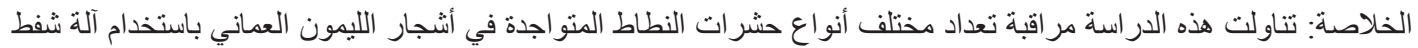

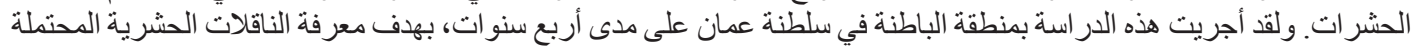

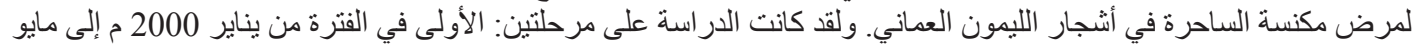

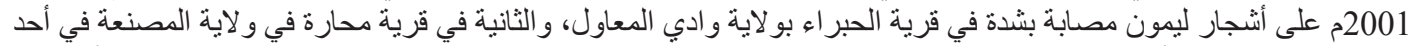

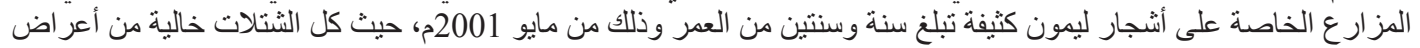

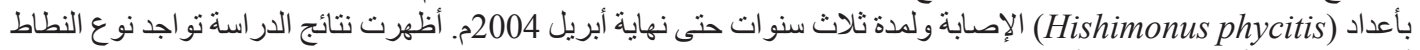

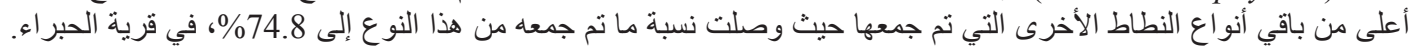

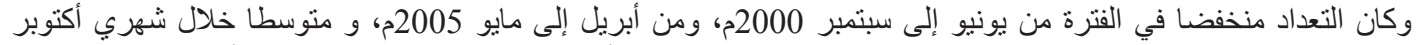

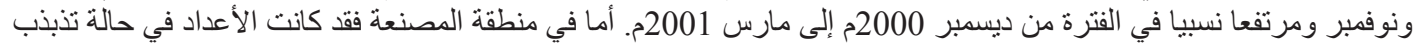

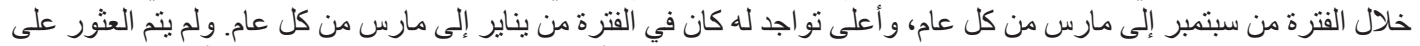

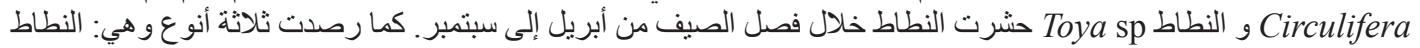

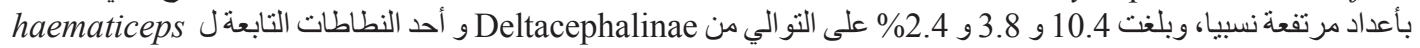
Exitianus

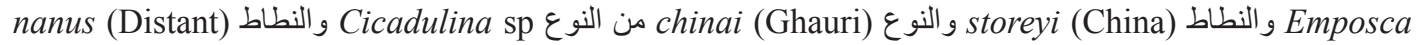
distinguenda (Paoli) و والنطاط Amrasca biguttula (Ishihara) والنطاط عecephalus (Recilia) pruthii

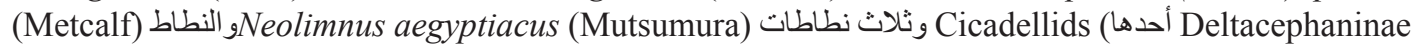

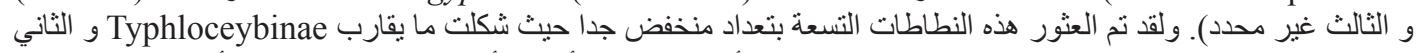

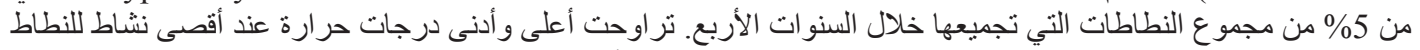

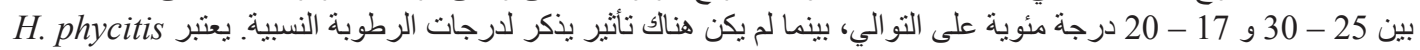

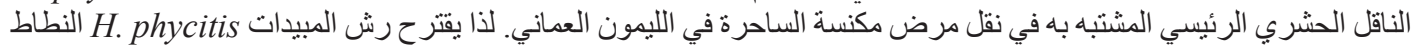

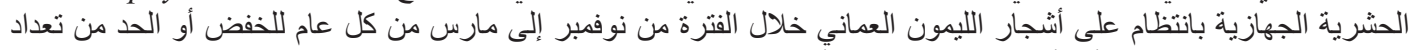

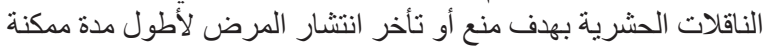

ABSTRACT: Regular monitoring of hemipteran hopper species (including psyllids) associated with small-fruited acid lime trees (Citrus aurantifolia L.) was conducted for four years using motorized insect suction to determine the possible vectors of witches'- broom disease of lime (WBDL). The study was done in two phases: monitoring was done in Habra village, Wilayat Wadi AlMaawal (Batinah region) for one year from June 2000 to May 2001; then monitoring was done in Maharah village, Wilayat AlMusannah (Batinah region), for a period of three years from May 2001 to April 2004. Twelve species of cicadellid

*Corresponding author. E-mail: sarazvi@hotmail.com 
leafhoppers and one delpahacid planthopper species were collected, while no psyllids were found. Hishimonus phycitis (Distant) (Cicadellidae) was the most abundant hopper (78.4\% of collected individuals). Next in abundance were Toya sp. (Delphacidae), Circulifera haematiceps? and a deltocephalin leafhopper, respectively constituting 10.4, 3.8 and $2.4 \%$ of the total catches of the four years. Nine other species made up 5\% of the total collection: Exitianus nanus (Distant), Cicadulina sp. (either chinai (Ghauri) or storeyi (China)), Emposca distinguenda (Paoli), Amrasca biguttula (Ishihara), Deltocephalus (Recilia) pruthii (Metcalf), Neolimnus aegyptiacus (Mutsumura) and three undetermined species (one Deltocephalinae, one Typhlocybinae and one undeterminable to subfamily). Catches of H. phycitis were highest from November to March and lowest from May to September. There was a significant linear relationship between number of $H$. phycitis and maximum and mininmum temperature. Relative humidity was not significantly correlated to number of $H$. phycitis. In Maharah, young lime trees were free from WBDL but the disease incidence increased with age. H. phycitis is the best candidate vector of WBDL. The potential of Toya sp., Circulifera haematiceps? and an undetermined deltocephalin as candidate vectors is discussed. Finally, it is suggested that regular sprayings of acid lime trees with effective systemic insecticides during November to March each year can greatly reduce the vector population and can prevent or delay the spread of the disease to a great extent.

Keywords: Pytoplasma, leafhopper, vector, witches broom disease of lime, Hishimonus phycitis.

\section{Introduction}

The small-fruited acid lime trees (Citrus aurantifolia L.) locally known as "Omani lime" are grown throughout the Sultanate of Oman. In the Sultanate these trees have been suffering from a widespread and lethal disease called witches'- broom disease of lime (WBDL) caused by the phytoplasma (previously referred to as mycoplasma-like organism, MLO) Candidatus Phytomplasma aurantifolia (Bove, 1995). The name of the disease reflects its most conspicuous symptoms: dense growth of very small pale green leaves, highly proliferated shoots, and reduction in length of inter-nodes. The disease slowly spreads to all branches and then the branches start drying. Later the whole plant dries and eventually dies within five years of appearance of the first symptoms of the disease.

The disease appears to have been present in Oman since the 1960's. Symptoms of the disease were first clearly reported in the mid seventies from AlBatinah region (Moghal et al., 1996). The disease was officially recognized in the early eighties, and in the mid eighties it epidemically exploded (Moghal et al., 1996). The disease progressed and spread very fast in the Batinah region, but other regions of northern Oman have not been spared from the disease. It has already destroyed lime orchards, especially in the Batinah, killing thousands of infected trees (Garnier et al., 1991; Bove, 1995), causing big losses to farmers. The disease is also found in the the United Arab Emirates and has recently been reported as destroying lime trees in Iran (Salehi et al., 1997). The disease has also been reported from India (Ghosh et al., 1999). Because of the rapid spread of the disease, an insect vector was suspected (Bove, 1995).
It is important to determine candidate vectors of WBDL as a first step in the process of arriving at the actual vector or vectors through transmission studies. To determine potential vectors of WBDL, we conducted regular monitoring of all the hemipteran hoppers (including psyllids) that are associated with acid lime trees in the Batinah. In addition, this study on the populations of hoppers associated with lime trees is expected to provide information on the peak acitivity period of the hoppers and will hopefully help in developing a suitable strategy to manage hoppers with the greatest potential to vector WBDL.

\section{Materials and Methods}

\section{Sampling}

Monitoring of populations of hemipteran hoppers (including psyllids), as potential vectors of WBDL, was done on acid lime trees at regular intervals at two farms in the southern Batinah. The study was done in two phases.

\section{Phase I: Monitoring hoppers associated with WBDL in a highly infected lime orchard}

Regular insect collections were done in an acid lime orchard highly infected with WBDL at Habra village (Wilayat Wadi AlMaawal, Batinah region) from June 2000 to May 2001 to provide preliminary information about the hoppers associated with WBDL. In this village the source of irrigation water was the falaj (spring water carried through ducts) and crops were flood-irrigated. Lime trees were more than 8 years old, closely spaced, and all were highly infected with WBDL. 
Insects were collected by vacuuming 20 lime trees for one hour, twice a month. The insect collection was done using a back-pack motorized insect suction sampler (UNIVAC portable, Burkard Scientific Company, U.K.). Vacuuming of insects was done up to a height of two meters on each tree, covering the outer and inner plant canopy. All the hoppers collected were sorted, based on their morphological characters and the hoppers collected were pooled on a monthly basis. All the hopper species to be identified were numbered and preserved in $75 \%$ ethanol.

\section{Phase II: Monitoring hoppers associated with a lime orchard intially free of $W B D L$}

To have a more complete assessment of the insects associated with acid lime trees, 56 young (1-2 years

a)

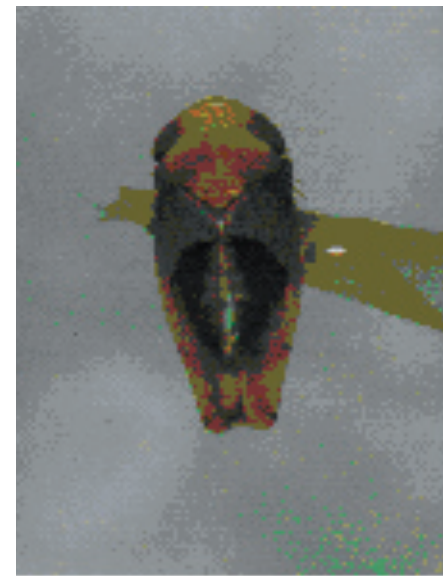

Hishimonus phycitis $78.4 \%$ catches

c)

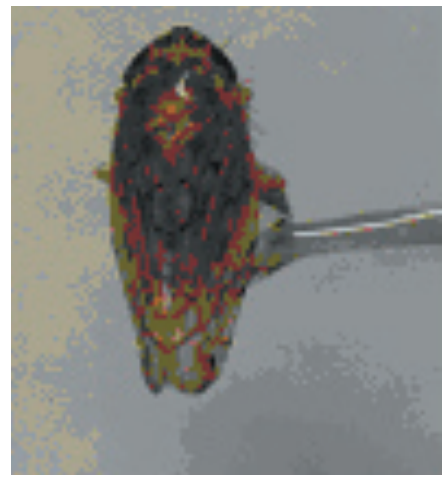

Circulifera haematoceps $3.8 \%$ catches

old) and WBDL-free (results of polymerase chain reaction (PCR) were negative) Omani acid lime trees from a private farm in Maharah village, Wilayat Musannah (Batinah region) were selected in the year 2001. The plants were under well- irrigation using an irrigation line fitted with bubblers. The spacing between trees was $8 \times 8.5 \mathrm{~m}$ and the area under the plants was cleanly cultivated. The presence of all the hoppers on these lime plants was monitored using an insect suction sampler (described above) twice a month, for one hour on each visit. On each tree, sampling was done up to a height of two meters, from both the outer and inner plant canopy. Monitoring was conducted for a period of three years, from May 2001 to April 2004. Collected hoppers were sorted, preserved in $75 \%$ ethanol, and unidentified forms

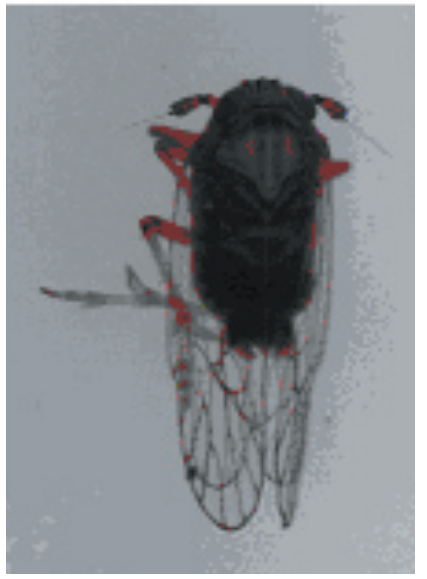

Toya sp $10.4 \%$ catches

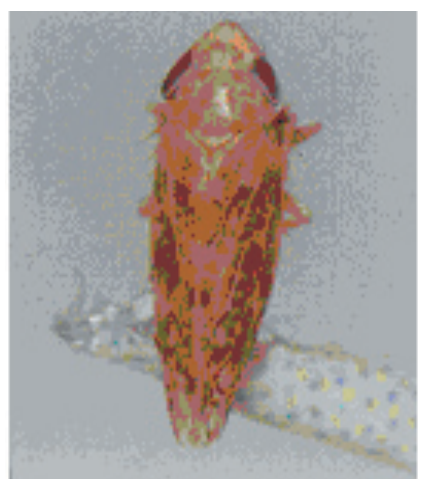

Deltocepalinae $2.4 \%$ catches b)

d)

Figure 1 a-d. Four most abundant collected hoppers. a. Hishimonus phycitis. b. Toya sp. c. Circulifera haematoceps. d. undetermined deltocephalinae. 
Table 1. Hopper species collected from witches'- broom diseased small fruited acid lime trees (Citrus aurantifolia) at Habra, Wilayat Wadi AlMaawal, Batinah region, Sultanate of Oman (June 2000 to May 2001). H. p. = Hishimonus phycitis. ${ }^{*}$ Other hoppers -1 . Circulifera haematoceps, 2. Deltocephalinae (Cicadellid), 3. Banus sp, 4. Exitianus nanus (Distant), 5. Cicadulina sp either chinai (Ghauri) or storeyi (China), 6. indeterminable (Cicadellid), 7. Toya sp (Delphacid), 8. Emposca distinguenda (Paoli), 9. Amrasca biguttula (Ishihara), 10. Typhlocybiane: Empoascini (Cicadellid), 11. Deltocephalus (Recilia) pruthii (Metcalf), 12. Neolimnus aegytiacus (Matsumura).

\begin{tabular}{|c|c|c|c|c|c|c|c|c|c|c|c|c|c|c|}
\hline \multirow{2}{*}{$\begin{array}{l}\text { Year/ } \\
\text { Month }\end{array}$} & \multirow{2}{*}{ H.p. } & \multicolumn{12}{|c|}{ Other Hopper Species Collected with Specimen Number* } & \multirow{2}{*}{ Tota } \\
\hline & & 1 & 2 & 3 & 4 & 5 & 6 & 7 & 8 & 9 & 10 & 11 & 12 & \\
\hline \multicolumn{15}{|l|}{2000} \\
\hline June & 10 & 2 & 0 & 0 & 0 & 0 & 0 & 0 & 0 & 0 & 0 & 0 & 0 & 12 \\
\hline July & 7 & 2 & 12 & 0 & 1 & 5 & 2 & 0 & 0 & 0 & 0 & 0 & 1 & 30 \\
\hline Aug & 10 & 7 & 0 & 0 & 0 & 0 & 0 & 2 & 0 & 0 & 0 & 0 & 0 & 19 \\
\hline Sept & 9 & 3 & 0 & 0 & 0 & 0 & 0 & 0 & 0 & 0 & 1 & 0 & 0 & 13 \\
\hline Oct & 18 & 0 & 0 & 0 & 0 & 0 & 0 & 0 & 0 & 0 & 0 & 0 & 0 & 18 \\
\hline Nov & 13 & 2 & 0 & 0 & 0 & 0 & 0 & 0 & 0 & 0 & 0 & 0 & 0 & 15 \\
\hline Dec & 49 & 0 & 0 & 0 & 0 & 0 & 0 & 0 & 0 & 0 & 0 & 0 & 0 & 49 \\
\hline \multicolumn{15}{|l|}{2001} \\
\hline Jan & 50 & 0 & 0 & 0 & 0 & 0 & 0 & 0 & 0 & 0 & 0 & 0 & 0 & 50 \\
\hline Feb & 38 & 0 & 0 & 0 & 0 & 0 & 0 & 0 & 0 & 0 & 0 & 0 & 0 & 38 \\
\hline Mar & 35 & 0 & 0 & 0 & 0 & 0 & 0 & 0 & 0 & 0 & 0 & 0 & 0 & 35 \\
\hline April & 10 & 5 & 0 & 3 & 0 & 1 & 0 & 0 & 0 & 1 & 0 & 0 & 0 & 20 \\
\hline May & 3 & 6 & 1 & 0 & 0 & 0 & 0 & 0 & 1 & 0 & 0 & 0 & 0 & 11 \\
\hline Total & 252 & 27 & 13 & 3 & 1 & 6 & 2 & 2 & 1 & 1 & 1 & 0 & 1 & 310 \\
\hline$\%$ of total & 81.3 & 8.7 & 4.2 & 1.0 & 0.3 & 1.9 & 0.6 & 0.6 & 0.3 & 0.3 & 0.3 & 0.0 & 0.3 & --- \\
\hline
\end{tabular}

were numbered. Abundance of collected hoppers were recorded on monthly basis.

All unknown hopper species collected during the four years study were sent to the Natural History Museum, London, for identification.

\section{Weather data and statistical analysis}

Data on maximum and minimum temperatures and mean relative humidity were recorded daily at the Meteorological Observatory, Agricultural Experiment Station, Rumais, which is the nearest observatory to Maharah. These data were used to calculate corresponding monthly averages of maximum and minimum temperature and relative humidity, which were in turn tested for relationships with the catches of hoppers from Maharah through correlation and regression analyses. Correlation and regression analyses were done separately for each of the three years using the data analysis tool of Microsoft Excel.

\section{Results and Discussion}

\section{Species composition and population dynamics}

\section{Phase I: Monitoring hoppers associated with WBDL in an infected lime orchard}

Data on hoppers collected from Habra during June 2000 to May 2001 (Table 1) indicate that the most abundant hopper (81.3\% of all specimens) caught on most collection dates was Hishimonus phycitis (Distant). This species was low in numbers during June to September 2000, with moderate numbers in October and November, and then reached peak catches from December 2000 to March 2001. With the onset of summer, the population started decreasing to low levels in April and May 2001. There were two other cicadellids, namely Circulifera haematoceps and an unidentified deltocephalin, both of which were caught in relatively large numbers (respectively 8.7 and 4.2 
Table 2. Hopper species collected from initially healthy small fruited acid lime (Citrus aurantifolia) plant at Maharah, Wilayat AlMusannah, Batinah region, Sultanate of Oman (May 2001 to April 2002). H. p. = Hishimonus phycitis. *For names of hopper species see Table 1 caption.

\begin{tabular}{|c|c|c|c|c|c|c|c|c|c|c|c|c|c|c|c|}
\hline \multirow{2}{*}{$\begin{array}{l}\text { Year/ } \\
\text { Month }\end{array}$} & \multicolumn{2}{|c|}{ H. $p$. } & \multicolumn{12}{|c|}{ Other Hopper Species Collected with Specimen Number* } & \multirow[t]{2}{*}{ Total } \\
\hline & A & $\mathrm{N}$ & 1 & 2 & 3 & 4 & 5 & 6 & 7 & 8 & 9 & 10 & 11 & 12 & \\
\hline \multicolumn{16}{|l|}{2001} \\
\hline May & 0 & 0 & 0 & 0 & 0 & 0 & 0 & 0 & 7 & 1 & 0 & 0 & 0 & 0 & 8 \\
\hline June & 0 & 0 & 0 & 0 & 0 & 0 & 0 & 0 & 0 & 0 & 0 & 0 & 0 & 0 & 0 \\
\hline July & 0 & 0 & 0 & 0 & 0 & 0 & 0 & 0 & 0 & 0 & 0 & 0 & 0 & 1 & 1 \\
\hline Aug & 0 & 0 & 0 & 0 & 0 & 0 & 0 & 0 & 0 & 0 & 0 & 0 & 0 & 0 & 0 \\
\hline Sept & 1 & 0 & 0 & 1 & 0 & 1 & 0 & 0 & 0 & 0 & 0 & 0 & 0 & 0 & 3 \\
\hline Oct & 2 & 0 & 0 & 0 & 0 & 0 & 0 & 0 & 0 & 0 & 0 & 0 & 0 & 0 & 2 \\
\hline Nov & 5 & 0 & 0 & 0 & 0 & 0 & 0 & 0 & 0 & 0 & 0 & 0 & 0 & 0 & 5 \\
\hline Dec & 6 & 0 & 0 & 0 & 0 & 0 & 0 & 0 & 0 & 0 & 2 & 0 & 0 & 0 & 8 \\
\hline \multicolumn{16}{|l|}{2002} \\
\hline Jan & 7 & 0 & 0 & 0 & 0 & 0 & 1 & 0 & 3 & 0 & 1 & 0 & 1 & 0 & 13 \\
\hline Feb & 3 & 0 & 0 & 0 & 0 & 0 & 0 & 0 & 0 & 0 & 0 & 0 & 0 & 0 & 3 \\
\hline Mar & 5 & 0 & 0 & 0 & 0 & 0 & 1 & 0 & 52 & 0 & 0 & 0 & 0 & 0 & 58 \\
\hline Apr & 9 & 0 & 0 & 1 & 1 & 0 & 0 & 0 & 1 & 0 & 0 & 0 & 0 & 0 & 12 \\
\hline Total & 38 & 0 & 0 & 2 & 1 & 1 & 2 & 0 & 63 & 1 & 3 & 0 & 1 & 1 & 113 \\
\hline$\%$ of total & 33.6 & 0.0 & 0.0 & 1.8 & 0.9 & 0.9 & 1.8 & 0.0 & 55.8 & 0.9 & 2.7 & 0.0 & 0.9 & 0.9 & --- \\
\hline
\end{tabular}

$\%$ of total catches). Nine more species of hoppers constituted $5.8 \%$ of caught specimens. These were the delphacid Toya sp. and eight cicadellids, namely: Banus sp, Exitianus nanus (Distant), Cicadulina sp. either chinai (Ghauri) or storeyi (China), Emposca distinguenda (Paoli), a typhlocybin (Empoascini), Amrasca biguttula (Ishihara), Neolimnus aegytiacus (Matsumura), and a species undeterminable to subfamily. These latter nine sepcies were mostly caught in the summer months.

It can be hypothesied that hoppers, especially $H$. phycitis, managed to build up their populations and be present throughout the year because of the optimal microhabitat in the Habra orchard. This is probably due to (i) close spacing of lime trees which were shaded by tall date palms, (ii) intercropping, (iii) growth habit of WBDL-affected limes and (iv) flood-irrigation.

\section{Phase II: Monitoring hoppers associated with a lime orchard intially free of WBDL}

2001-2002: In addition to $H$. phycitis, nine other hopper species were collected during May 2001-April 2002, when the lime plants were apparently healthy and young (Table 2). They were the delphacid Toya sp, and the cicdaellids: Banus sp, Exitianus nanus (Distant),
Cicadulina sp either chinai (Ghauri) or storeyi (China), Emposca distinguenda (Paoli), Amrasca biguttula (Ishihara), Deltocephalus (Recilia) pruthii (Metcalf), Neolimnus aegytiacus (Matsumura), and an unidentified deltocephalin.

Adult $H$. phycitis constituted $33.6 \%$ of the total catches. The catches of this species in general were low but relatively high in December 2001, and in January and April 2002 (Table 2). On the other hand, Toya sp. numbers were exceptionally high, amounting to $55.8 \%$ of the total catches. Most of these $(83 \%)$ were collected in March 2002. This indicates that there was a brood of Toya sp. which emerged in March 2002. The total catches of the other hoppers were very low, constituting together only $10.6 \%$ of total catches.

2002-2003: In the year May 2002 to April 2003, when the plants were 2-3 years old, the total catches of H. phycitis increased to 124 (Table 3 ) from 38 in the previous annual period. There were no catches of H. phycitis in May to September 2002. The catches were very low during October and November 2002 and April 2003. Most of the catches of this species ocurred during December 2002 to March 2003. The results obtained during this year indicated that, 
Table 3. Hopper species collected from initially healthy small fruited acid lime plant (Citrus aurantifolia) at Maharah, Wilayat AlMusannah, Batinah region, Sultanate of Oman (May 2002 to April 2003). H. p. = Hishimonus phycitis. *For names of hopper species see Table 1 caption.

\begin{tabular}{|c|c|c|c|c|c|c|c|c|c|c|c|c|c|c|c|}
\hline \multirow{2}{*}{$\begin{array}{l}\text { Year/ } \\
\text { Month }\end{array}$} & \multicolumn{2}{|c|}{ H. $p$. } & \multicolumn{12}{|c|}{ Other Hopper Species Collected with Specimen Number* } & \multirow{2}{*}{ Total } \\
\hline & A & $\mathrm{N}$ & 1 & 2 & 3 & 4 & 5 & 6 & 7 & 8 & 9 & 10 & 11 & 12 & \\
\hline \multicolumn{16}{|l|}{2002} \\
\hline May & 0 & 0 & 0 & 0 & 0 & 1 & 0 & 0 & 0 & 0 & 0 & 0 & 0 & 0 & \\
\hline June & 0 & 0 & 0 & 0 & 0 & 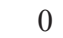 & 0 & 0 & 0 & 0 & 0 & 0 & 0 & 0 & 0 \\
\hline July & 0 & 0 & 0 & 0 & 0 & 0 & 1 & 0 & 0 & 0 & 0 & 0 & 0 & 0 & 1 \\
\hline Aug & 0 & 0 & 0 & 0 & 0 & 0 & 0 & 0 & 0 & 0 & 0 & 0 & 0 & 0 & 0 \\
\hline Sept & 0 & 0 & 0 & 0 & 0 & 0 & 0 & 0 & 0 & 2 & 0 & 0 & 0 & 0 & 2 \\
\hline Oct & 1 & 0 & 0 & 0 & 0 & 0 & 0 & 0 & 0 & 1 & 0 & 0 & 0 & 0 & 2 \\
\hline Nov & 5 & 0 & 0 & 0 & 0 & P & 0 & 0 & 0 & 2 & 0 & 0 & 0 & 0 & 7 \\
\hline Dec & 37 & 7 & 0 & 0 & 0 & 0 & 0 & 0 & 0 & 0 & 0 & 0 & 0 & 0 & 44 \\
\hline \multicolumn{16}{|l|}{2003} \\
\hline Jan & 30 & 4 & 0 & 1 & 0 & 0 & 0 & 0 & 0 & 1 & 0 & 0 & 0 & 0 & 36 \\
\hline Feb & 21 & 1 & 0 & 0 & 0 & 0 & 0 & 0 & 1 & 0 & 0 & 0 & 0 & 0 & 23 \\
\hline March & 12 & 0 & 0 & 0 & 1 & 0 & 0 & 0 & 1 & 2 & 0 & 0 & 0 & 0 & 16 \\
\hline April & 6 & 0 & 0 & 0 & 0 & 0 & 0 & 0 & 0 & 0 & 0 & 0 & 0 & 0 & 6 \\
\hline Total & 112 & 12 & 0 & 1 & 1 & 1 & 1 & 0 & 2 & 8 & 0 & 0 & 0 & 0 & 138 \\
\hline$\%$ of total & 81.2 & 8.7 & 0.0 & 0.7 & 0.7 & 0.7 & 0.7 & 0.0 & 1.4 & 5.8 & 0.0 & 0.0 & 0.0 & 0.0 & --- \\
\hline
\end{tabular}

in addition to $H$. phycitis, six other hoper species were found on lime trees. They were the delphacid Toya sp., the cicdaellids: Banus sp, Exitianus nanus (Distant), Cicadulina sp either chinai (Ghauri) or storeyi (China), and Emposca distinguenda (Paoli) and an unidentified deltocephalin. H. phycitis was consistently seen in large number (adults and nymphs constituted $89.9 \%$ of total catches). These six other hopper species together constituted $10.1 \%$. Among the other hoppers, Emposca distinguenda was the most abundant, constituting $57 \%$ of all other hoppers caught (Table 3 ).

2003-2004: During the period extending from May 2003 to April 2004, the trend with regard to the catches of $H$. phycitis remained the same. Total numbers of this species increased to 178 , which amounted to $93.5 \%$ (adults and nymphs) of the total catches (Table 4). The other four hopper species caught were the delphacid Toya sp. and the cicadellids: Emposca distinguanda, Cicadulina sp., and an unidentified deltocephalin. Among these other hoppers, the most abundant (3.9\% of total catches) was Toya sp., which was caught only during January to March 2004.

\section{General patterns}

\section{Composition of hopper species}

Pooled data of hopper species on acid limes for the four year study is presented in Table 5 for comparison. No psyllids were caught during the four years. The total catch of $H$. phycitis was very high (581 specimens), representing $78.4 \%$ of the total catches. Twelve other hopper species were collected during the four years study. Among these, three hopper species were caught in relatively large numbers: Toya sp (74 specimens), followed by Circulifera haematiceps (27 specimens) and undetermined deltocephalin (17 specimens) (Table 5). Fig. 1 a-d shows the latter four most abundant hoppers. Other less abundant leafhopper species were: Emposca distinguenda (Paoli), Cicadulina sp (either chinai (Ghauri) or storeyi (China)), Banus sp., Amrasca biguttula (Ishihara), Exitianus nanus (Distant), Neolimnus aegyptiacus (Mutsumura), undetermined (Cicadellid), Deltocephalus (Recilia) pruthii (Metcalf), and undetermined Typhloceybin. These latter nine species were extremely low in numbers, over a period of four years, suggesting that 
Table 4. Hopper species collected from initially healthy small fruited acid lime plant (Citrus aurantifolia) at Maharah, Wilayat AlMusannah, Batinah region, Sultanate of Oman (May 2003 to April 2004). H. p. = Hishimonus phycitis. *For names of hopper species see Table 1 caption.

\begin{tabular}{|c|c|c|c|c|c|c|c|c|c|c|c|c|c|c|c|}
\hline \multirow{2}{*}{$\begin{array}{l}\text { Year/ } \\
\text { Month }\end{array}$} & \multicolumn{2}{|c|}{ H. $p$. } & \multicolumn{12}{|c|}{ Other Hopper Species Collected with Specimen Number* } & \multirow{2}{*}{ Total } \\
\hline & A & $\mathrm{N}$ & 1 & 2 & 3 & 4 & 5 & 6 & 7 & 8 & 9 & 10 & 11 & 12 & \\
\hline \multicolumn{16}{|l|}{2003} \\
\hline May & 1 & 0 & 0 & 0 & 0 & 0 & 0 & 0 & 0 & 1 & 0 & 0 & 0 & 0 & 2 \\
\hline June & 0 & 0 & 0 & 0 & 0 & 0 & 0 & 0 & 0 & 0 & 0 & 0 & 0 & 0 & 0 \\
\hline July & 0 & 0 & 0 & 0 & 0 & 0 & 0 & 0 & 0 & 0 & 0 & 0 & 0 & 0 & 0 \\
\hline Aug & 1 & 0 & 0 & 1 & 0 & 0 & 0 & 0 & 0 & 0 & 0 & 0 & 0 & 0 & 2 \\
\hline Sept & 0 & 0 & 0 & 0 & 0 & 0 & 0 & 0 & 0 & 0 & 0 & 0 & 0 & 0 & 0 \\
\hline Oct & 1 & 0 & 0 & 0 & 0 & 0 & 1 & 0 & 0 & 1 & 0 & 0 & 0 & 0 & 3 \\
\hline Nov & 2 & 0 & 0 & 0 & 0 & 0 & 0 & 0 & 0 & 0 & 0 & 0 & 0 & 0 & 2 \\
\hline Dec & 16 & 3 & 0 & 0 & 0 & 0 & 0 & 0 & 0 & 0 & 0 & 0 & 0 & 0 & 19 \\
\hline 2004 & & & & & & & & & & & & & & & \\
\hline Jan & 30 & 11 & 0 & 0 & 0 & 0 & 0 & 0 & 1 & 0 & 0 & 0 & 0 & 0 & 42 \\
\hline Feb & 38 & 3 & 0 & 0 & 0 & 0 & 0 & 0 & 4 & 0 & 0 & 0 & 0 & 0 & 45 \\
\hline March & 30 & 3 & 0 & 0 & 0 & 0 & 0 & 0 & 2 & 0 & 0 & 0 & 0 & 0 & 35 \\
\hline Apr & 27 & 1 & 0 & 0 & 0 & 0 & 0 & 0 & 0 & 0 & 0 & 0 & 0 & 0 & 28 \\
\hline Total & 146 & 21 & 0 & 1 & 0 & 0 & 1 & 0 & 7 & 2 & 0 & 0 & 0 & 0 & 178 \\
\hline $\begin{array}{l}\% \text { of } \\
\text { total }\end{array}$ & 81.7 & 11.8 & 0.0 & 0.6 & 0.0 & 0.0 & 0.6 & 0.0 & 3.9 & 1.1 & 0.0 & 0.0 & 0.0 & 0.0 & --- \\
\hline
\end{tabular}

they cannot be the vectors of WBDL, given the rapid rate of disease spread.

\section{Possible vectors of WBDL}

Since H. phycitis was collected in large numbers and was present on most of the collection dates, it appears that it may be the most likely vector of WBDL, as also suggested by Bove et al. (1988) and Koizumi (1995). Furthermore, this insect was also reported as a vector of phytoplasma disease on other crops. In plants such as periwinkle (Catharanthus roseus) it transmits periwinkle little leaf disease (Kar and Panda, 1990). In India it is known to transmit a phytoplasma disease called little leaf disease of eggplant (Srinivisan and Chelliah, 1978). Interestingly, H. phycitis has long been known in India, and acid lime is known as one of the hosts plants on which this leafhopper is able to live and multiply (Bindra and Singh, 1969). Thus $H$. phycitis is the number one candidate, but the presence of three more hopper species (Toya sp, Circulifera haematiceps and an undetermined Deltocephalin) in significant numbers means that these species should be considered as candidates vectors no. 2, 3 and 4 for WBDL. Since H. phycitis is considered as the number one candidate vector, we will focus on its population dynamics and the weather conditions during its peak population period.

\section{Population dynamics of $H$. phycitis and effects of temperature and relative humidity}

The population fluctuations of $H$. phycitis during the four year study are depicted in Fig. 2. It clearly shows that population fluctuations followed similar trends during the four years. The peak activity period was between November and March, while the population decreased to low levels between April and September.

H. phycitis catches and the maximum and minimum temperatures during each of three year annual periods in Maharah are plotted together in each of Figs. 3 a-c, which indicate that the maximum and minimum temperatures during the peak activity periods of $H$. phycitis ranged from 25 to $30^{\circ} \mathrm{C}$ and from 17 to $20^{\circ} \mathrm{C}$, respectively.

In order to determine whether there was an association between temperature and relative humidity on the one hand and H. phycitis numbers on the other hand, the monthly catches of $H$. phycitis during the three year study at Maharah were correlated with monthly 
Razvi and others

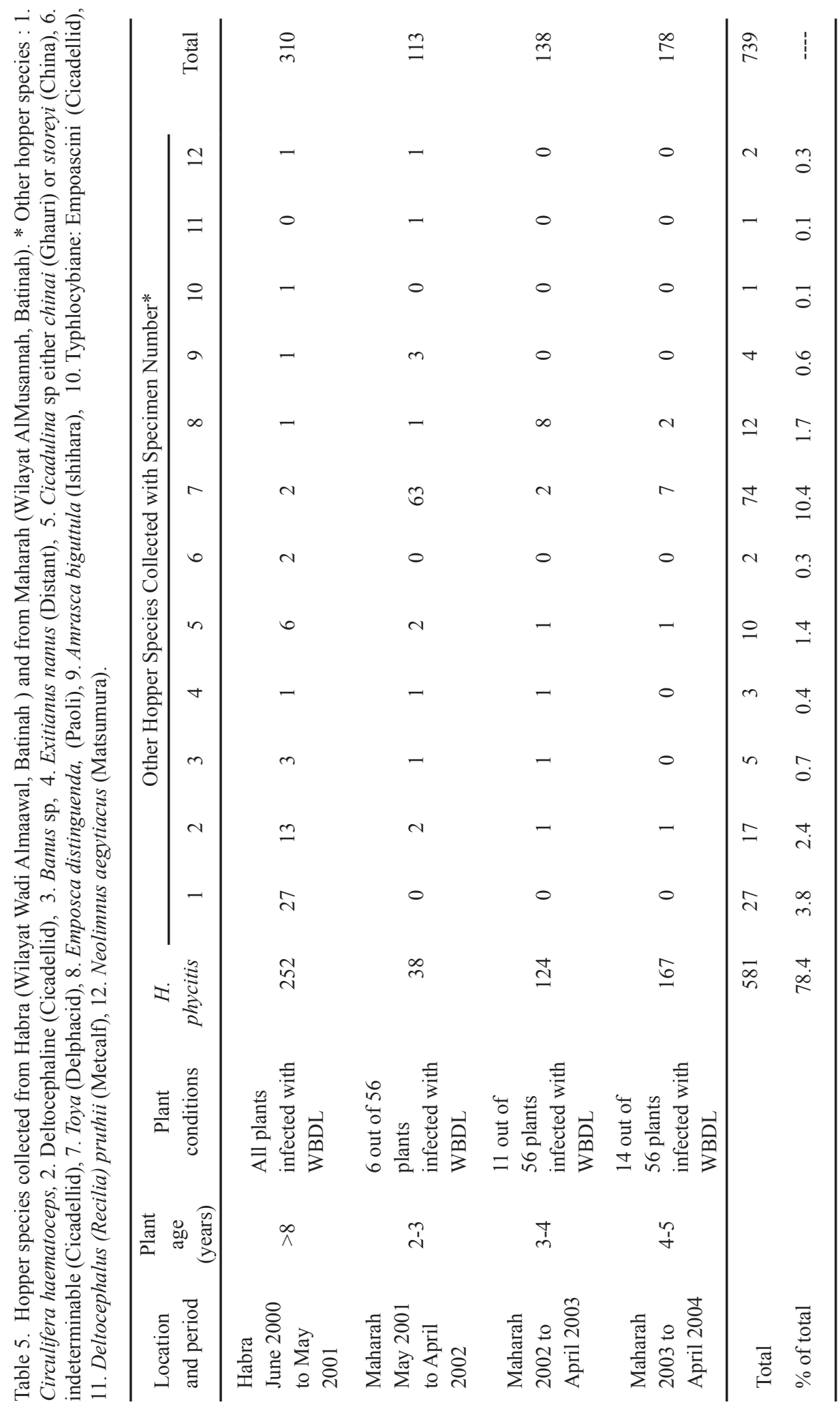




\begin{tabular}{|l}
$\rightarrow-$ June 2000 - April $2001-$ May 2001 - April 2002 \\
$\Delta-$ May 2002 - April $2003 \rightarrow$ May 2003 - April 2004 \\
\hline
\end{tabular}

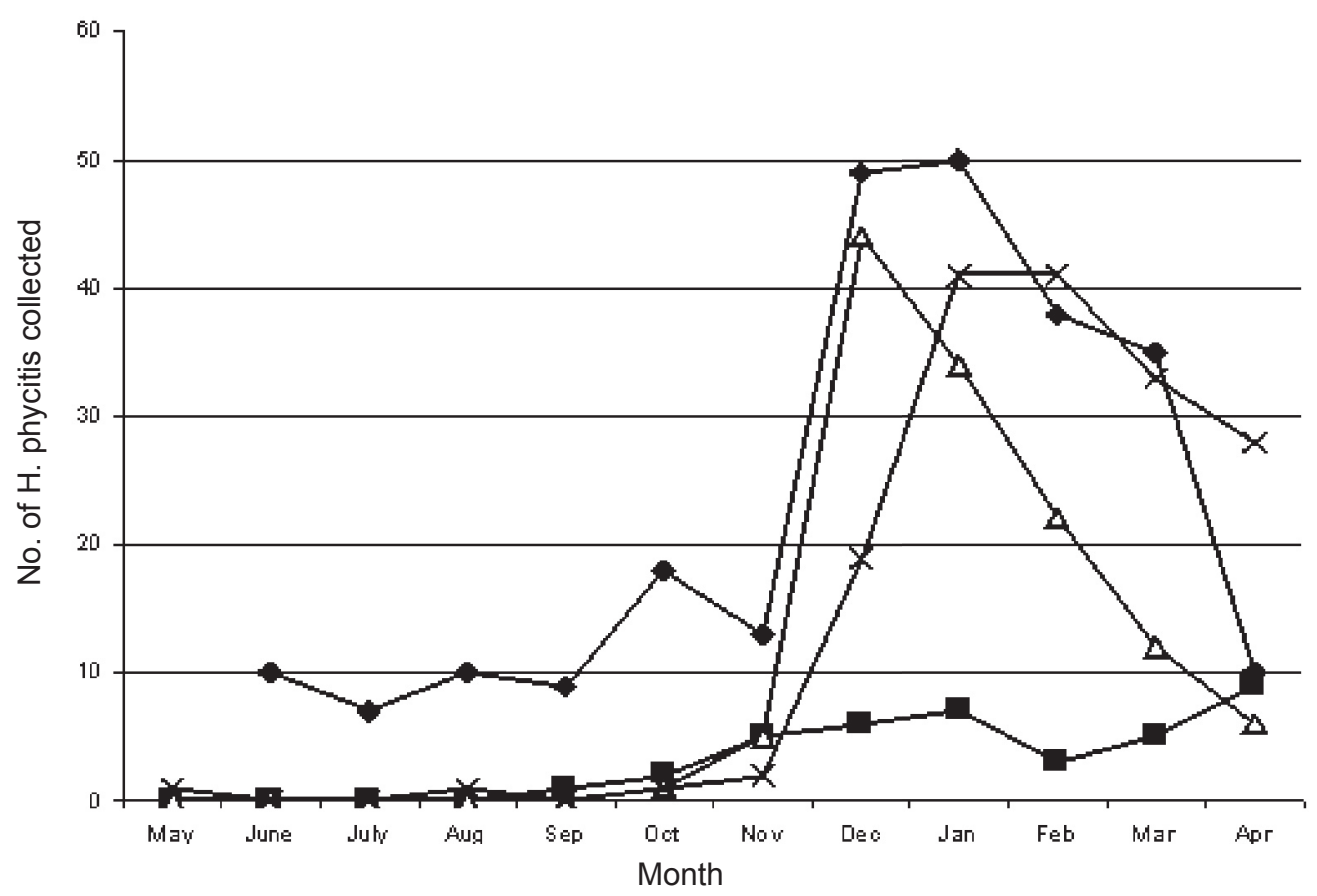

Figure 2. Population fluctuations of H. phycitis on small fruited acid lime plants (June 2000 to April 2004).

average maximum and minimum temperatures and with relative humidities. It is evident that a significant negative correlation existed between the catches of $H$. phycitis and maximum and minimum temperatures. The ' $r$ ' values for the regression of catches against maximum and minimum temperatures during the year 2001-2002 were -0.64 and $-0.70(\mathrm{p}<0.05)$, respectively (Table 6). The ' $r$ ' values for the regression of catches against maximum and minimum temperatures during the year 2002-2003 and 2003-2004 were -0.82 and $0.82(\mathrm{p}<0.01)$, and $-0.68(\mathrm{p}<0.05)$ and $-0.76(\mathrm{p}<0.01)$, respectively (Table 6 ). The ' $r$ ' values for maximum and minimum temperatures of the three years pooled data were -0.62 and $-0.66(p<0.05)$, respectively. Relative humidity did not show any significant correlation with numbers of $H$. phycitis (Table 6). Linear regression analysis was conducted to predict population numbers of $H$. phycitis from mean maximum and minimum temperatures based on pooled data from the three years of monitoring in Maharah. The linear equations and regression lines are presented in Figure 4.

\section{Relationships between $\mathrm{H}$. phycitis population and the age and disease condition of lime trees}

In Maharah total catches of $H$. phycitis were low in numbers (38) when the plants were young (2-3 years old) and increased with age. The number of specimens caught was 124 when the plants were 3-4 years old, and increased to 167 when the plants attained the age of 4-5 years. The $H$. phycitis total annual catch recorded in Habra (252) was relatively higher than the other 3 annual catches recorded from Maharah. The Habra orchard had infected plants eight years and older in age. Direct comparisons cannot be made between Habra and Maharah. However, due to the close proximity of the two locations, the data from Habra provides some support to the idea that the population of H. phycitis in Maharah could have increased with 
a)

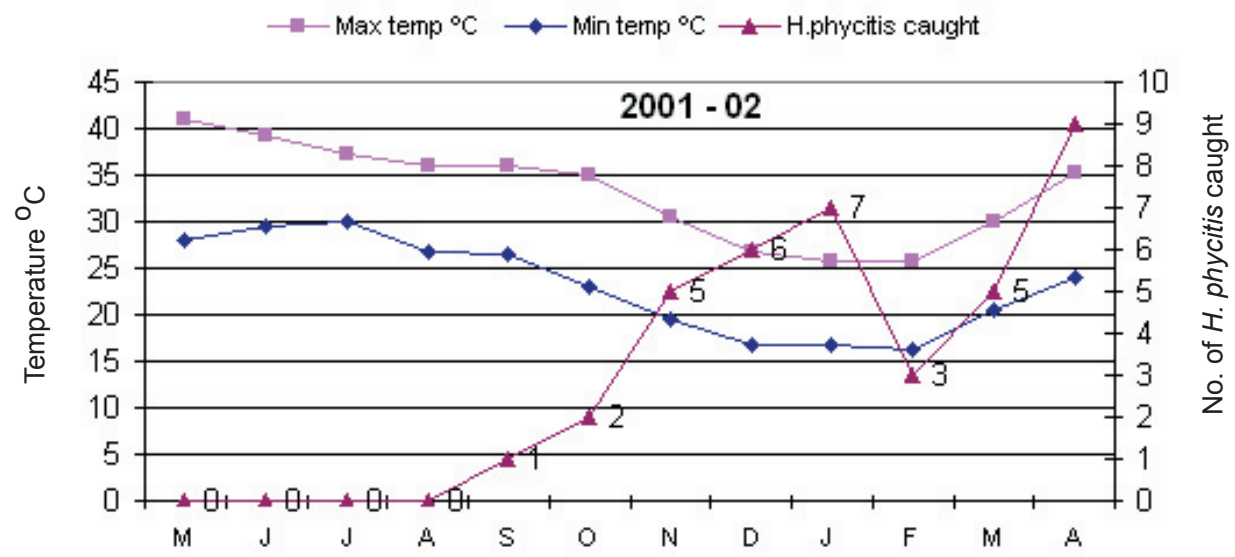

b)

Month

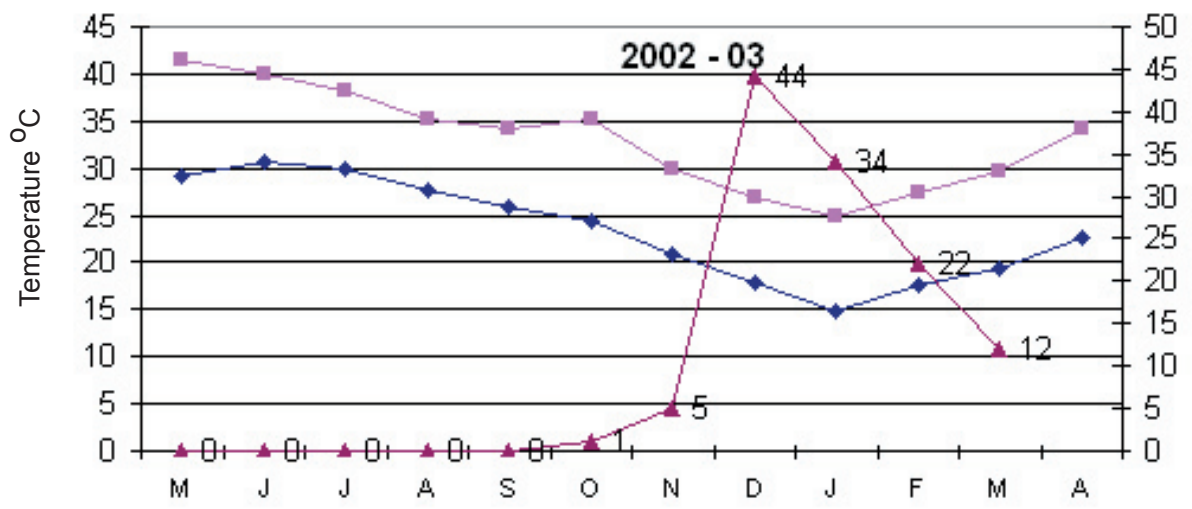

c)

Month

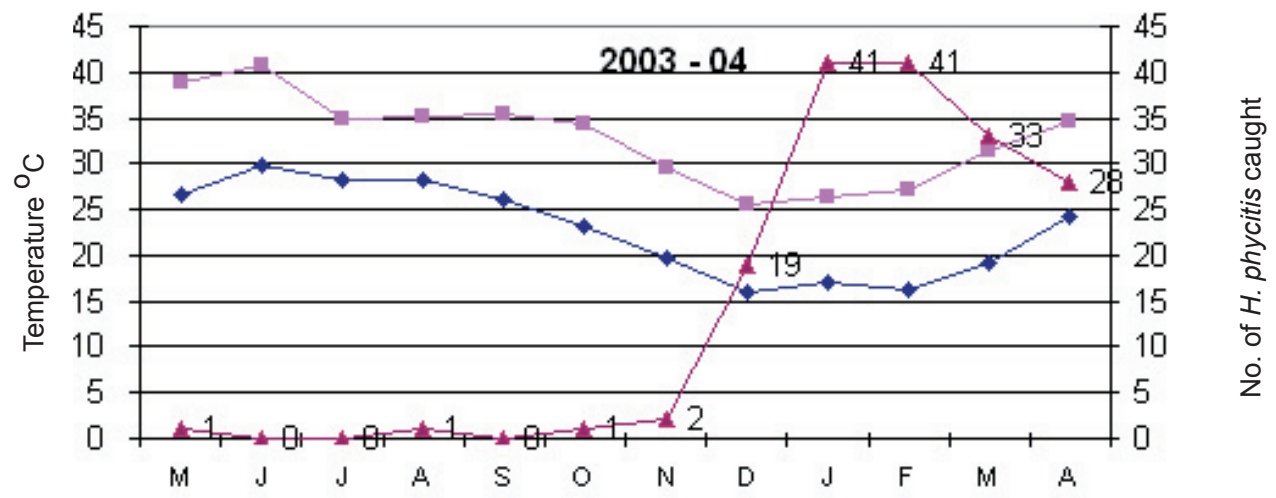

Month

Figure 3a-c. Effect of temperature on the population fluctuations of H. phycitis on lime trees in Maharah (Al Musanah Wilayat) from May 2001 to April 2004. 
a)

$$
r=-0.62^{*} \quad Y=65.18-1.70 X
$$

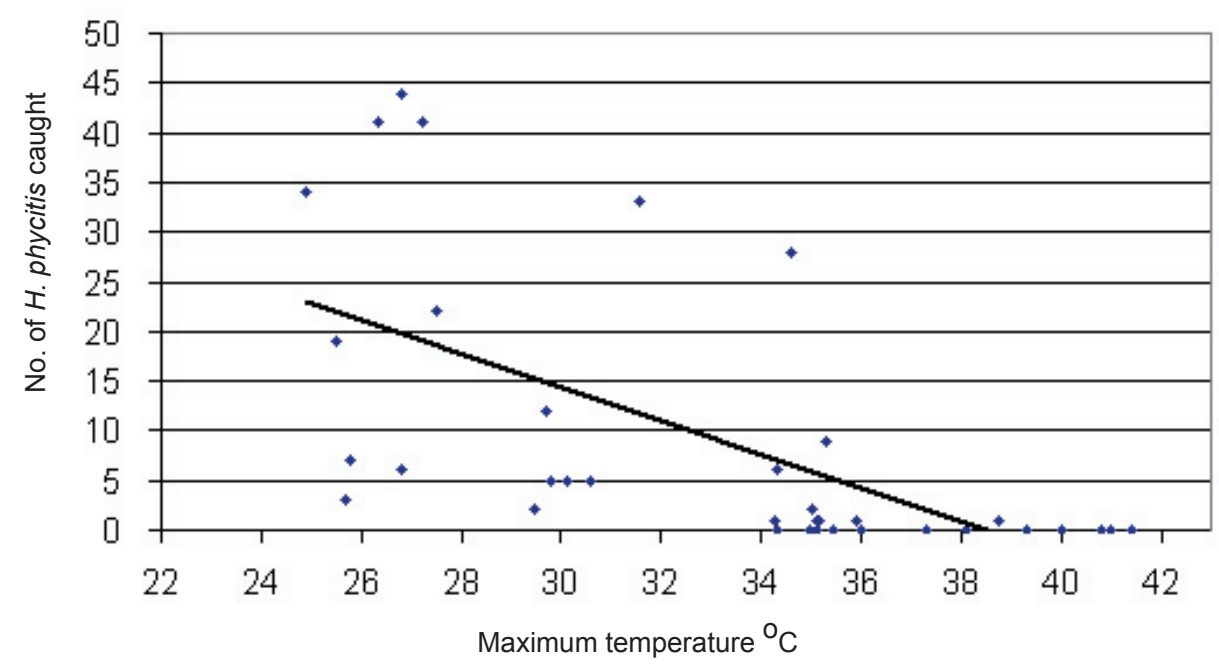

b)

$$
r=-0.66^{*} \quad Y=50.64-1.79 X
$$

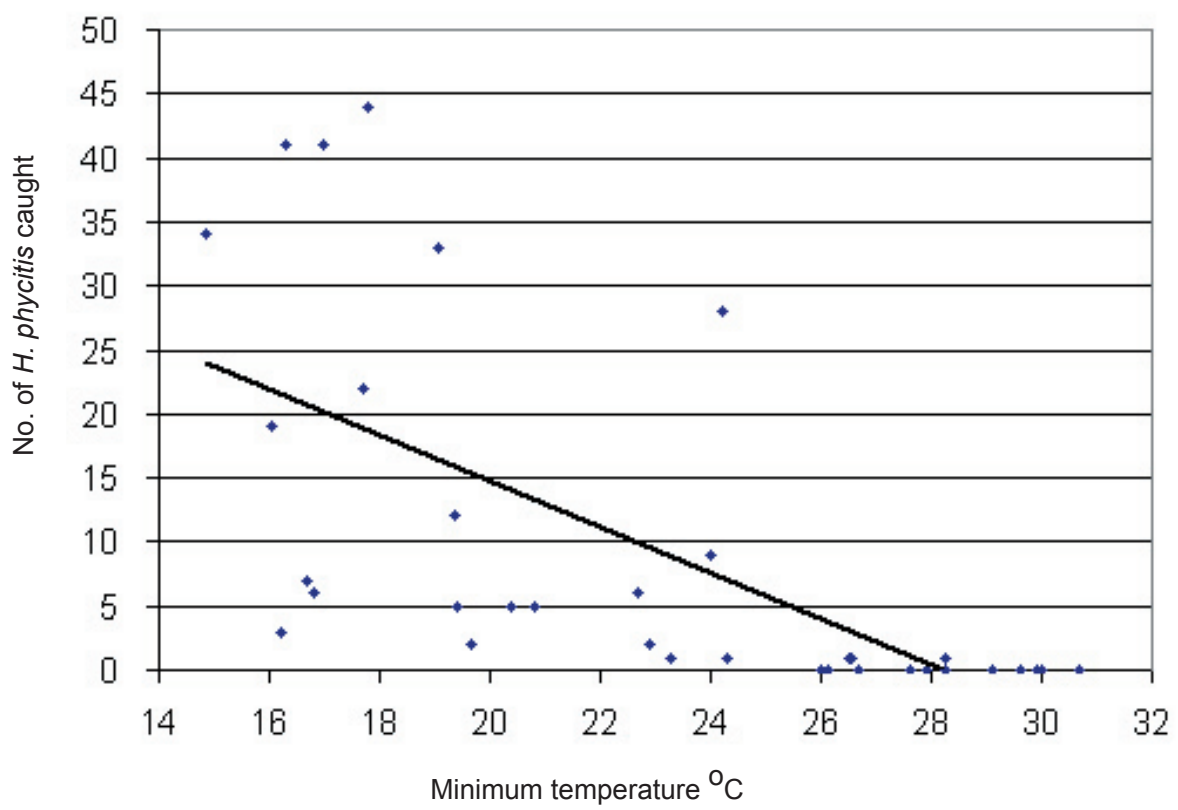

Figure $4 \mathrm{a}-\mathrm{b}$. Relationship between the catches of $H$. phycitis and maximum and minimum temperatures in Maharah (Al Musanah Wilayat) from May 2001 to April 2004. a) Relationshp with maximum temperature. b) Relationship with minimum temperature. 
Table 6. Correlations between catches of Hishominus phycitis and weather factors at Maharah (May 2001 to April 2004). *Significant at $\alpha=0.05 . * *$ Significant at $\alpha=0.01 . \mathrm{NS}=$ not significant.

\begin{tabular}{|c|c|c|c|c|c|c|c|}
\hline \multirow[b]{3}{*}{ Year } & \multirow{3}{*}{$\begin{array}{c}\text { Mean } \\
\text { Catches } \\
\pm \mathrm{SD}\end{array}$} & \multicolumn{4}{|c|}{ Temperature ${ }^{\circ} \mathrm{C}$} & \multirow{2}{*}{\multicolumn{2}{|c|}{$\begin{array}{c}\text { Mean } \\
\text { Relative humidity \% }\end{array}$}} \\
\hline & & \multicolumn{2}{|c|}{ Maximum } & \multicolumn{2}{|c|}{ Minimum } & & \\
\hline & & $\begin{array}{l}\text { Mean } \\
\pm \text { SD }\end{array}$ & $\begin{array}{l}\text { Correlation } \\
\text { Coefficient } \mathrm{r}\end{array}$ & $\begin{array}{l}\text { Mean } \\
\pm \text { SD }\end{array}$ & $\begin{array}{l}\text { Correlation } \\
\text { Coefficient } r\end{array}$ & $\begin{array}{c}\text { Mean } \\
\pm \text { SD }\end{array}$ & $\begin{array}{c}\text { Correlation } \\
\text { Coefficient } \mathrm{r}\end{array}$ \\
\hline 2001-02 & $3.2 \pm 3.2$ & $33.2 \pm 5.3$ & $-0.64 *$ & $23.1 \pm 5.1$ & $-0.70^{*}$ & $55.4 \pm 8.0$ & $-0.13 \mathrm{NS}$ \\
\hline $2002-03$ & $10.3 \pm 15.1$ & $33.1 \pm 5.3$ & $-0.82 * *$ & $23.4 \pm 5.4$ & $-0.82 * *$ & $60.8 \pm 11.1$ & $0.10 \mathrm{NS}$ \\
\hline 2003-04 & $13.9 \pm 17.3$ & $32.8 \pm 4.9$ & $-0.68^{*}$ & $22.9 \pm 5.1$ & $-0.76^{* *}$ & $56.4 \pm 9.9$ & $-0.11 \mathrm{NS}$ \\
\hline $\begin{array}{l}\text { Pooled } \\
\text { analysis }\end{array}$ & $9.1 \pm 13.7$ & $33.1 \pm 5.0$ & $-0.62 *$ & $23.1 \pm 5.0$ & $-0.66^{*}$ & $57.5 \pm 9.8$ & $0.03 \mathrm{NS}$ \\
\hline
\end{tabular}

the increase in age of lime trees, possibly due to the increase of plant canopy with age. This could have provided more congenial micro-climatic conditions for the H. phycitis to build up its population.

The catches of H. phycitis were very high in plants infected with WBDL in Habra (Table 1). It appears that this leafhopper species has a preference to feed, thrive and multiply on diseased branches. The exact reason is not known. However, the diseased branches have soft tissues, smaller leaves, and reduced internodes. This could make microenvironmental conditions more congenial for the hopper to build up its population. Another explanation for the preference of $H$. phycitis for diseased parts of lime trees is the altered physiology of diseased host tissues, as suggested by Srinivasan and Chelliah (1979) and Raghuraman (1968). Srinivasan and Chelliah (1979), while studying the biology of $H$. phycitis, found a significant difference in incubation period, nymphal period and adult longevity between healthy and little-leaf diseased eggplants. According to these authors the adult longevity of $H$. phycitis was significantly longer on diseased plants (23 days) than on healthy plants ( 9 days). A similar finding was made by Murral et al. (1996) who reported that the aster leafhopper Macrosteles quadrilineatus lived longer on aster yellow phytoplasma-diseased plants than on healthy plants.

\section{Progress of WBDL in Maharah}

All 56 plants at Maharah in 2001 (start of the study) were free from WBDL. Six plants started showing

Table 7. Appearance of witches'- broom disease of lime (WBDL) in small fruited acid lime plants (Citrus aurantifolia) on which hopper species were monitored (at Maharah during 2001 -2004).

\begin{tabular}{|c|c|c|c|c|c|c|c|c|c|c|c|c|c|c|c|}
\hline \multirow{4}{*}{$\begin{array}{l}\text { Plant Age } \\
\text { (yrs) }\end{array}$} & \multicolumn{12}{|c|}{$\begin{array}{l}\text { No. of Plants Showing Symptoms of } \\
\text { WBDL in the Month of }\end{array}$} & \multirow{4}{*}{$\begin{array}{c}\text { Total } \\
\text { No. of } \\
\text { Pants } \\
\text { with } \\
\text { WBDL } \\
\text { Symptoms }\end{array}$} & \multirow{4}{*}{$\begin{array}{c}\text { Cumulative } \\
\text { Total of } \\
\text { WBDL } \\
\text { Infected } \\
\text { Plants }\end{array}$} & \multirow{4}{*}{$\begin{array}{c}\% \\
\text { Plants } \\
\text { Showing } \\
\text { WBDL } \\
\text { Symptoms }\end{array}$} \\
\hline & $\mathrm{J}$ & $\mathrm{F}$ & M & A & M & $\mathrm{J}$ & $\mathrm{J}$ & A & $\mathrm{S}$ & $\mathrm{O}$ & $\mathrm{N}$ & $\mathrm{D}$ & & & \\
\hline & A & $\mathrm{E}$ & A & $\mathrm{P}$ & A & $\mathrm{U}$ & $\mathrm{U}$ & $\mathrm{U}$ & $\mathrm{E}$ & $\mathrm{C}$ & $\mathrm{O}$ & $\mathrm{E}$ & & & \\
\hline & $\mathrm{N}$ & $\mathrm{B}$ & $\mathrm{R}$ & $\mathrm{R}$ & $\mathrm{Y}$ & $\mathrm{N}$ & $\mathrm{L}$ & G & $\mathrm{P}$ & $\mathrm{T}$ & $\mathrm{V}$ & $\mathrm{C}$ & & & \\
\hline 2 & \multicolumn{12}{|c|}{ All plants were free from symptoms of WBDL } & 0 & 0 & 0.0 \\
\hline 3 & 0 & 0 & 0 & 0 & 3 & 0 & 3 & 0 & 0 & 0 & 0 & 0 & 6 & 6 & 10.71 \\
\hline 4 & 0 & 0 & 0 & 0 & 0 & 2 & 2 & 1 & 0 & 0 & 0 & 0 & 5 & 11 & 19.64 \\
\hline 5 & 0 & 0 & 0 & 0 & 0 & 0 & 2 & 1 & 0 & 0 & 0 & 0 & 3 & 14 & 25.00 \\
\hline Total & 0 & 0 & 0 & 0 & 3 & 2 & 7 & 2 & 0 & 0 & 0 & 0 & - & - & - \\
\hline
\end{tabular}


symptoms of WBDL at the age of three years. As time passed more plants started showing symptoms and by 2004, 14 plants (25\% of all plants) showed symptoms of WBDL (Table 7). It is also interesting to note that new records of symptomatic trees were made during the hotter months (May to August) in each of three years of monitoring in Maharah (Table 7).

\section{Practical implications of the study}

Because H. phycitis is the predominant hopper (Table 5) and was present on most collection dates (Fig. 2), it is the top potential vector. It is also clear from Figure 2 that during the entire four years study, the population of H. phycitis was mostly observed during NovemberMarch. It is suggested that regular applications of effective systemic insecticides during this peak population period could control the population of the vector and consequently may check the spread of WBDL.

\section{References}

Bindra, O.S. and B. Singh. 1969. Biology and bionomics of Hishimonus phycitis Distant), a jassid vector of "little-leaf" disease of brinjal (Solanum melongena L.) Indian Journal of Agricultural Science 39:912-919.

Bove, J.M. 1995. Virus and virus like diseases of citrus in the Near East region, Oman (chapter 16), p. 217-238. Food Agriculture Organisation of United States, Rome pp 518.

Bove J.M., M. Garnier, A.M. Mjeni and A. Kharyallah. 1988. Witches'- broom disease of lime trees in Oman: First MLO disease of citrus. In: Proceeding $10^{\text {th }}$ Conference. IOCV, p 307-309, Riverside, University of California.

Garnier M., L. Zreik and J.M. Bove. 1991. Witches'broom a lethal disease of lime trees in the Sultanate of Oman and the United Arab Emirates. Plant Disease 75:546 -551.

Ghosh, D.K., A.K. Das, Shayam Singh, S.J. Singh, Y.S. Ahlawat, and S. Singh. 1999. Occurrence of witches'- broom, a new phytoplasma disease of acid lime (Citrus aurantiifolia) in India. Plant Disease 83:302.
Kar, R.K. and R.K. Panda. 1990. Transmission of periwinkle little leaf disease. Indian Journal of Mycology and Plant Pathology 20:188-189.

Koizumi, M. 1995. Virus or virus like diseases of citrus in tropical and sub tropical zones. In: First International Symposium in Fruit Production in the Tropics and Sub-tropics, Kyoto, Japan, 22 - 23 August 1994. Trukuba, Japan. Japan International Research Center for Agricultural Sciences. International Symposium Series (1995) No. 3, 61-66.

Moghal, S.M., A.D. Al-Zadjali and A. Al-Matrooshi. 1996. Studies on witches'- broom disease of lime. Annual Report 1996 of Agricultural Research Center, Rumais, Ministry of Agriculture and Fisheries.

Murral, D.J., L.R. Nault, C.W. Hoy, L.V. Madden and S.A. Miller. 1996. Effects of temperature and vector age on transmission of two Ohio strains of aster yellows phytoplasma by the aster leafhopper (Homoptera: Cicadellidae). Journal of Economic Entomology 89:1223-1232.

Raghuraman, T.V. 1968. Preference of the aleyrodid Bemisia tabaci Genn., for bhendi plants infected with yellow vein mosaic virus with particular reference to the biochemical mechanism. Unpublished M.Sc. (Ag.) thesis, University of Madras, India.

Salehi, M., K. Izadpanah and H. Rahimian. 1997. Witches'- broom disease of lime in Sistan, Baluchistan. Iranian Journal of Plant Pathology 33:3-4, 76.

Srinivasan, K. and S. Chelliah. 1978. Influence of time of planting and weather factors on brinjal eggplant little leaf incidence and its vector Hishimonus phycitis (Distant). South Indian Horticulture 26:79-80.

Srinivasan, K. and S. Chelliah. 1979. Studies on the biology of Hishimonus phycitis, vector on healthy and little leaf diseased brinjal (Solanum melongena L.) Eggplants. Madras Agricultural Journal Coimbatore 66:395-400.

Received: December 2005

Accepted: May 2006 